\title{
Feasibility Analysis Functions of Iranian Universities in Achieving Sustainability
}

\author{
Mehdi Zakerian ${ }^{1}$, Zeinab Sadoughi ${ }^{2}$, Abdolamir Nabavi $^{3} \&$ Reza Mahdi $^{3}$ \\ ${ }^{1}$ Faculty of Law and Political Sciences, Islamic Azad University, Iran \\ ${ }^{2}$ Department of Cultural Policy Making, Institute for Social and Cultural Studies, Tehran, Iran \\ ${ }^{3}$ Institute for Social and Cultural Studies, Tehran, Iran \\ Correspondence: Mehdi Zakerian, Faculty of Law and Political Sciences, Islamic Azad University, Iran. E-mail: \\ m-zakerian@srbiau.ac.ir
}

Received: February 1, 2017

Accepted: February 27, 2017

Online Published: March 30, 2017

doi:10.5539/jsd.v10n2p191

URL: https://doi.org/10.5539/jsd.v10n2p191

\begin{abstract}
Realization of sustainable development requires role-playing of various institutions in order to promote and institutionalize the values of sustainability. One of the important actors in the pursuit of this purpose is universities, and according to most of analysts, promotion of sustainability depends on the formation of sustainable universities. This study aimed to investigate the role and position of university in realizing sustainable development. For this purpose, the concept of sustainability and its dimensions and also the role of university in developing the values related to sustainability and empowerment of human resources were investigated through descriptive - analytic study and according to its results, in-depth interview was used to interview with ten experts in this field about how to realize this aim within the universities. Results showed that there is direct relationship between academic activities and promotion of the values of sustainability if structures and mechanisms of universities evolve purposively. In recent years, some universities have taken concrete steps in this regard, but at the Iranian universities, aside from some scattered efforts, the formation and development of activities related to sustainability were inadequate. So, only with accurate policies and targeted programs, it can be hoped to realize development based on the values of sustainability through the functions of universities.
\end{abstract}

Keywords: higher education, university, sustainable university, sustainability, sustainable development

\section{Introduction}

The concepts of sustainability and sustainable development are the words frequently heard. In any areas, scholars argue that the main principle is sustainability and its values and principles must be promoted; from an environmental activist to the economist, from an engineer to a sociologist, all of them consider sustainability as a priority, although they have different perceptions of this concept and look at it from their particular perspectives. The important note is that how is more sustainable world realized? Beyond the differences between the analysts' viewpoints in various fields, it is believed that education is a main tool in order to introduce the principles of sustainability to individuals (Unesco, 2004). Actually, in the current era, there is a need to use effective strategies for sustainable development at national and international levels and there is a consensus that education is the driving force of this process.

Accordingly, the question is that what role does and position does university, as the most important educational institution at higher level, have in the realization of sustainable development? It is believed that education is the most important factor in making individuals aware of the principles of sustainability and promoting its effects in human society, converting knowledge to sustainability-based action and finally, holding peace in human relationships. Education also requires the strong support of research that can help education to form and promote new paradigm based on sustainable development and university is a place to produce literature and to promote and institutionalize the teachings related to sustainability. Accordingly, in present study, realization of sustainability was investigated in terms of actions and functions of the university. Present study is a library and descriptive study in terms of data collection and it is qualitative study in terms of analysis method. Experts' opinions were used in qualitative analysis. Ten professors and experts were interview in depth based on theoretical saturation and the findings were analyzed qualitatively. The results showed that there is direct 
relationship between academic activities and promotion of the values of sustainability if structures and mechanisms of universities evolve purposively. During the interview, some information about the situations of Iranian universities in pursuit of this objective was obtained that implies on the inadequacy of the measures taken at the universities in Iran.

\section{Sustainability}

The term "sustainability" was firstly raised in forestry issues and it meant to prevent excessive use of forests and rangelands (Grober, 2007). The concept of sustainability is old while it is new, too. In earlier cultures, sustainability meant continuity and respect for the traditions, but due to increased political power and accelerated economic growth, the idea of "progress forever" has become the core subject of political and economic debates (Partidario, 2010). The difficulties (inequality, poverty, discrimination, industrial pollution, disease, etc.) caused by economic development in the last century led that the concept of sustainability has been taken into consideration more than ever. But when the concept of sustainability is discussed, the first concept that comes into mind is environment and its conservation. According to some researchers, sustainable development is defined as the development along with environmental considerations.

Since the World Commission on "Environment and Development" in 1987, raised the issue of sustainable development has been raised seriously. A report published by the Commission, entitled "Brundtland", sustainable development was defined as meeting the needs of the present generation without compromising the ability of future generations to exploit resources and meet their needs (Kates \& Parris \& Leiserowitz, 2005). But, sustainability is not limited only to economic and environmental issues and accordingly, in recent years, social sustainability, which is related to social justice and also, is a way to hold peace, has been considered (Winston, 2011), while, this meaning has been neglected in many contexts related to sustainability.

So, it cannot be thought just in terms of previous paradigms because they and the concepts, values and principles of social sustainability are not convergent. Therefore, after the introduction of the term "sustainable development" in the 1980s, integrating new paradigm of development in other institutions of society (politics, economy, culture, education, etc.) has been gradually stressed (McKenzie, 2004). Paradigm of sustainability looks to the future and considers qualitative growth and human development which is beyond quantitative growth considered in former views. This issue was mentioned in UNDP: "development is a multifaceted responsibility for achieving high quality life for all people. Economic, social and environmental development are interdependent and mutually formative factors of sustainable development." (UN, 1997). It is important that all three factors are considered in realization of sustainability. It means that in the field of environment, it must be understood that benefiting healthy environment is a civil right which has been taken into consideration in the third generation of human rights (Molaei, 2007). In economic dimension, paying attention to high quality is important and sustainable development is defined beyond mere economic quantitative growth (Doane, 2001). Also, society is sustainable in terms of social aspect that:

- People can unlock their total abilities in their lives grow intellectually and be prepared to work and participate in social activities and enjoy life.

- People can increase their knowledge and understanding of local, regional and global requirements and procedures.

- People can play a role in shaping a democratic, civilized and enlightened society.

- People can accelerate the exchange of ideas and opinions to develop a knowledge-based society and to promote integration and participation in the activities for the development.

- People can assess and validate the technical achievements to increase the benefits of knowledge-based society (Afgan \& Carvalho, 2010).

So, sustainability is relevant to several concepts, such as poverty alleviation, peace, ethics, responsibility, democracy, good governance, justice, human rights, cultural diversity, production and consumption patterns and environmental protection and it is achieved when people accept the principles of respect and maintenance of community, living with kindness and love, establishing democratic, fair, participatory, sustainable, peaceful and maintenance of land resources for current and future generations societies (Javdani and Nili monfared, 2013). Achieving this insight depends on the knowledge; there is a need to people who has social-cultural insight in addition to economic capabilities. Here, the role of educational institutions and university is important.

\section{Sustainability through Academic Actions}

Whitehead said that the university should enable people to create new enlightened image of the world and link 
information and experience together (Delanti, 2007). In discourse of development in the sense of mere economy, academic efforts are performed to encourage and facilitate it, but, now, given that social dimensions of development and discussion of sustainability have been taken into account, it is appropriate that the efforts are organized under the functions of teaching, research and social services (Brubacher, 1977).

Universities should equip students with the ability of decision making and enhance their ability of problem-solving. With academic training, students should be familiar with the culture of tolerance and learn to respect for diversity and differences; students should learn how to look at facts critically and challenge them and from this perspective, recognize the factors of unsustainability and its negative consequences correctly, so, the change in mind and thinking are the most important priority of education. Education with participatory learning, democratic society, environmental sensibility and fundamental thinking can deal with the risk of error and illusion (Moran, 2005). Education can encourage students to be better citizens and to apply their knowledge in the solution of global issues (Ferrer-Balas, 2005). In general, sustainable development needs holistic people with systematic thinking, interdisciplinary, informed, creative and participatory insights and universities are the place for nurturing these individuals (Mousaei and Ahmadzadeh, 2009). Toh and Cawaga believe that by training, people learn to have a comprehensive understanding of the roots and causes of conflicts, inequalities and instabilities and during training, they are exposed to a wide range of different opinions and this increases critical thinking and makes people more willing to take action based on peace and justice, and to try more in this way (Toh \& Cawagas, 1989). According to Cortese, in general, higher education institutions have an in-depth and moral responsibility to raise awareness, to transfer knowledge and to develop the capabilities needed to create and maintain a sustainable future based on justice (Cortese, 2003). These trainings are taken through open and hidden curriculum. The role of education is very important so that United Nations, after the World Summit on Sustainable Development in Johannesburg in 2002, called for global efforts related to all levels of educationfrom primary education to all levels of higher education- to address the challenge of sustainable development and called the years 2005-2014 as the "Decade of Education for Sustainable Development" (Kildahl, 2009).

At the present time, we need to have a new paradigm and way of thinking that university play an important role in shaping this paradigm and transferring its values. In fact, in order to move towards sustainability as well as to meet difficulties ahead, human needs to produce knowledge to look at these issues with new subjective system. Production of social justice knowledge is the main subject of peace and sustainability in the world; this knowledge is released in the education sector, and if this task is done correctly, it will lead to the nurture of global citizenship with a global shared vision and it will bring sustainability, peace and eradicate violence; because it is believed that poverty in capability caused by cognitive poverty. Accordingly, in developed countries, the role of universities is to produce knowledge with the aim of training human resources.

Scientific and academic research should produce and promote the knowledge that results in increased awareness of the mutual rights, familiarity with the concept of change, knowledge of the laws and regulations in order to establish order and responsibility, familiarity with the relationship between human and environment, knowledge of peace and how to achieve it, knowledge of social justice and equal opportunities, knowledge of differences between humans and prevention of conflicts and resolving them without violence and knowledge of what modern man needs to know. Also, how to enhance individual skills in this area should be investigated; how people can be encouraged to participate, how people can be taught to respect mutual rights and understandings, to dialogue, to accept diversity, to understand environment, ..., are the issues that should be studied and finally, they lead to the change in mentalities and attitudes. What is important in the views of many researchers is the unity of teaching and research. This must be considered as the key feature of higher education institutions. This considers science as a problem which is always unsolved and so, it is involved in ongoing research (Smarandache, 2012).

Another function of higher education in promoting the values of sustainability is its role in providing social services. Achievements of university in the field of knowledge production is not limited only to students and it is important that other individuals who are not in classes and at university, can benefit these achievements. For example, universities can hold short-term training courses about different issues and provide their achievements to other people. If universities and higher education institutions do their duties well, it can be expected to shape knowledge-based society. This society has environmental, economic and social insight and knowledge. Figure 1 shows the relationship between knowledge-based society and sustainability. 


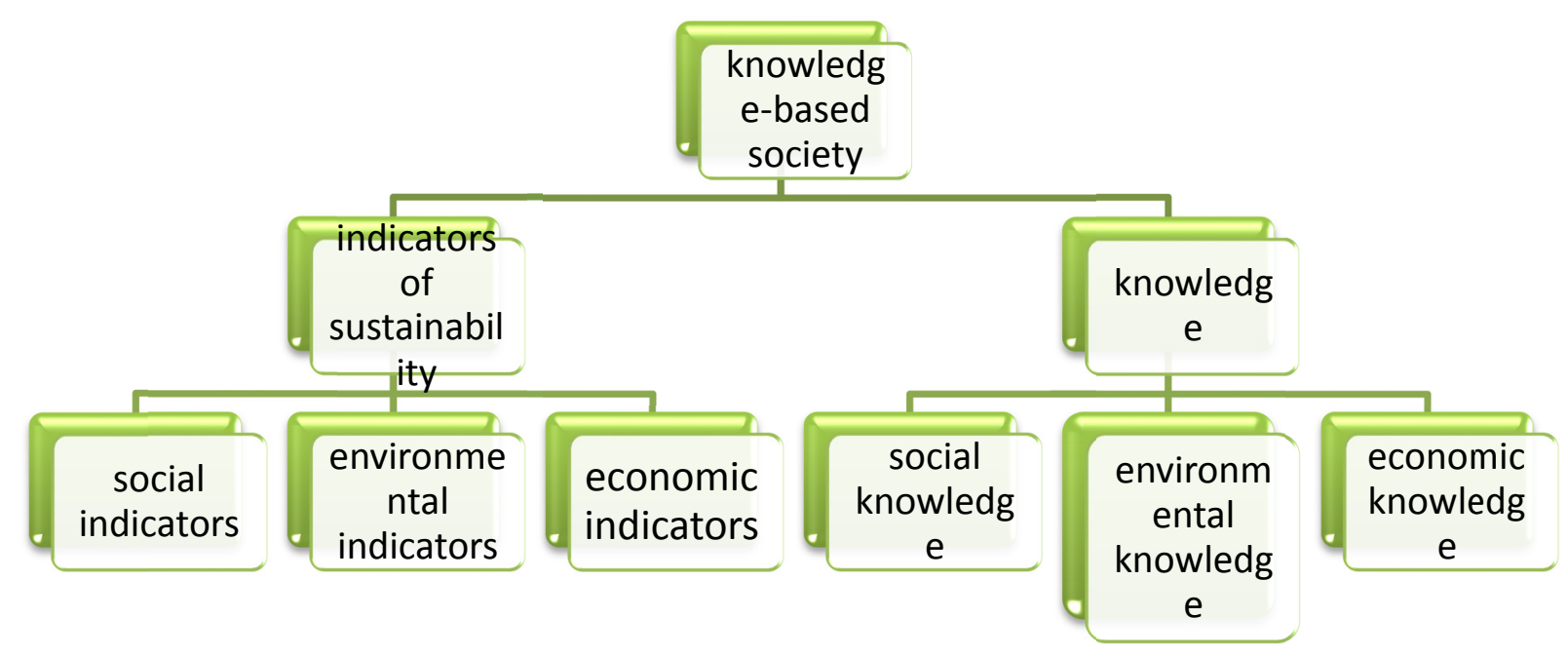

Figure 1. The relationship between knowledge and sustainability (Afgan \& Carvalho, 2010)

As shown in Figure 1, knowledge-based society is a society based on equality between knowledge and indicators of sustainability. In general, the emergence of the knowledge-based society has increase the importance and priority of learning and in the meantime, universities are important because they are the place of education, research and innovation and also, driving force of development.

\section{Characteristics of Sustainable University}

University can be a ground of promotion and development of sustainability which is pluralistic in addition to independent, creates balance between education, research and social services, provides ample opportunity for students and teachers to do scientific activities and moves in line with the principle of academic freedom (Brubacher, 1977). Sustainable university emphasizes on evolutionary training rather than mere transitional training and instead of one-way learning process, it believes that evolutionary training must be more interactive and learner-centered along with strengthening critical thinking and emphasize on interdisciplinary science and it believes that the process of research and education should move towards solving social problems and empowering students and take specific management system tailored to adapt to social changes (Maleki nia et al., 2014). According to Calder and Smith, in sustainable university, sustainability must be institutionalized in all fields. There would be accurate planning for the education of students and even professors in the education sector, the research must be supported, especially, some incentives must be considered for interdisciplinary research. In this way, university can be referred as the focus of sustainability. Also, such sustainability can be seen in social services of university, its policy and students' lives (Calder \& Smith, 2009). This university must be based on interdisciplinary teaching and emphasize on the learning based on individual's active participation. In such learning, professor just provides tools for students and the student tries to achieve educational goals by him/herself (Steiner and Posch, 2006). Maleki nia et al., in their study entitled "identification and prioritization of the components of sustainable university", referred to some criteria of sustainable university, as listed in Table1. 
Table1. The criteria related to the components of sustainable university

\begin{tabular}{ll}
\hline Main components & Sub-components \\
& Integration of sustainable development in the vision of university \\
& The establishment of sustainable development office or unit \\
& University stakeholders' participation in decision-making \\
& Observing principles of equality in the use of opportunities \\
\hline Sustainable management & Cooperation between universities \\
system & Choosing academic manager with democratic way \\
& The annual assessment of university sustainability \\
& Social responsibility and accountability to stakeholders \\
& Appreciation of the efforts related to sustainable development \\
& Intra- and Interdisciplinary curriculum system \\
\hline Sustainable education system & Fostering critical and systemic thinking skills \\
& Environmental literacy \\
& The use of heuristic, participatory and etc. teaching- learning approach \\
& Intra- and interdisciplinary research \\
& Orienting toward solving environmental, social, economic problems \\
\hline Avoiding mere commercial look at research \\
Supporting research projects related to sustainable development \\
Academic freedom \\
Attracting financial support for research related to sustainability from external \\
sources
\end{tabular}

Different opinions have been raised about sustainable university. In present study, it has been tried to provide solutions for achieving sustainable university based on "Van Weenen" sustainable university model (Van Weenen, 2000). According to him, in order to achieve sustainability, any university faces with some questions such as why university participates in the process, what measures are required and how to organize the activities. This model has been designed with three axes, as shown in figure 2 . 


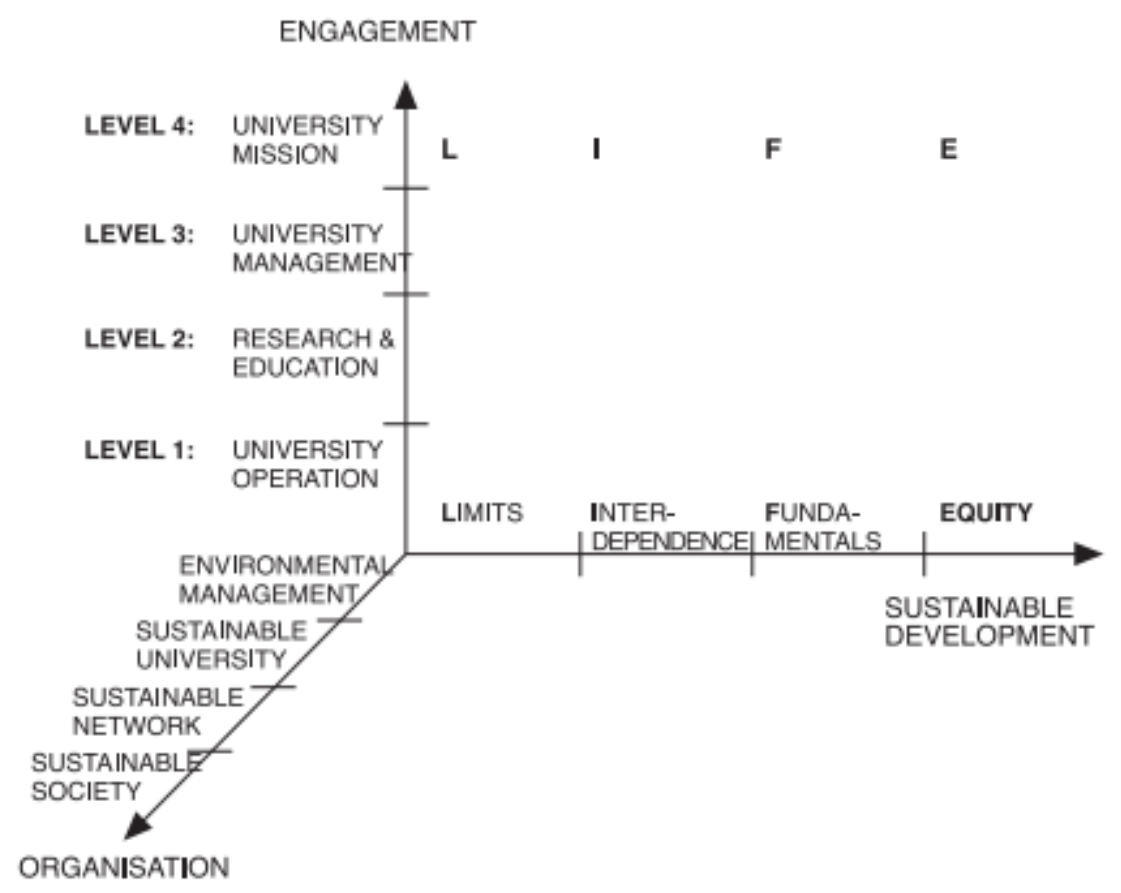

Axis of organization: Environmental management, Sustainable university, Sustainable network, Sustainable society

Figure2. The classification model of sustainable university (Van Weenen, 2000)

Answering the question "why?", "What measure?" And "How?" is the first step of universities in moving towards sustainability. About why sustainability is important, the importance of its realization and promotion of related values were mentioned. About the role of universities in the realization of this goal, it was tries to investigate how they can play a role based on the views of experts.

\section{Method and Results}

In terms of data collection, it is library and descriptive study. In this section, the concepts of sustainability, sustainable development and the role of education institutions have been investigated in pursuit of this goal. In terms of analysis method, this study is qualitative-analytical study. In this section, according to theoretical saturation, in-depth interview was used to interview 10 professors and analysts and the findings were analyzed qualitatively and also they were used to suggest solutions. The samples were selected by purposive sampling method and also they were selected among people who have more convenient information about the topic. The most important factors in selecting them were their field of expertise and the field of their studies. About why universities participate in realization of sustainable development, the interviewees emphasized on the concepts of "collective responsibility" and "collective will". Development requires collective action and the share of each sector should be determined in the field. All the interviewees believed that human is informed, wise, thinker and creative and can make the world safe and healthy and so, education is a key of development and sustainability. In response to the question that can university play a key role in promotion of sustainability or not, all the interviewees believed that university is an effective institutions in promotion of the principles of sustainability, hence, in many countries, the universities have redefined their roles in the comprehensive development; but if the experiences of universities in Iran are reviewed, it will be found that, sustainable development based on environmental considerations, along with environmental concerns in the global arena, have been considered somewhat in the universities in Iran. For example, the establishment of the Office of Sustainable Development at the Amir Kabir University of Technology in $2011^{1}$ and/or the measures taken in Sharif University of Technology, Iran university of Science and Technology and other universities or the global rankings of Zanjan University on indicators of sustainable development ${ }^{2}$ and holding numerous national and international conferences by the

\footnotetext{
${ }^{1}$ Sustainability.aut.ac.ir

${ }^{2}$ http://www8.irna.ir/fa/News/82051364/
} 
universities in Iran. But, it should be said that there have been very partial and sporadic efforts to develop the environment sustainably. If the development process be considered linear process; from economic growth to economic development, sustainable development, sustainability and post-sustainability, it is believed that over time, the development model desired in Iran and its higher education has not experienced the discussion of sustainability and post-sustainability (Zaker Salehi, 2013). In Iran, the universities have not seriously addressed the social aspects of sustainability, the issues of equality, peace and just neither in terms of content nor educational and research programs. The interviewees have stressed on interdisciplinary education and collaborative learning as a teaching tool. In this regard, in recent years, some universities have taken some measures; at some universities have established some disciplines with interdisciplinary contents, of course, they are at the beginning of the way and these programs requires serious progress; they should be excluded from personal experience or intra-university mode and placed at the priority of policy-makers' planning. Collaborative learning has not been usually accepted as a principle in the universities in Iran (although some professors consider collaborative learning as the main principle), also, universities have no specific plan for seminar and joint classes between universities for exchange of ideas and thoughts and/or international student exchanges. We need to go beyond the paradigm of sustainable development and to have comprehensive planning in the fields of achieving a comprehensive sustainability and using all the available tools and above all, academic system by adopting a macro approach. While, some developed countries take effective steps in this regard by understanding the importance of the issue. For example, in American, a more than $\$ 50$ million budget was considered to identify the types of content, to revise the theories of teaching and learning in higher education system in 2008 (Akhondi et al., 2013).

About the question "what should universities do in this regard?", the answers of interviewees were in the form of functions of universities as follows:

\section{Academic Education and Sustainability}

Firstly, about the role of universities in promoting sustainability, the interviewees emphasized on the educational activities. In this section, developing special curriculum was highlighted as far as some of them knew the establishment of a discipline with the same title as the best academic efforts to promote the principles of sustainability. One of the professors in Educational Sciences said: "it is better to include two unit of general courses in curriculum in addition to the courses of literature and religious knowledge so that all the students, even the students in other disciplines such as technical and engineering disciplines, become familiar with the literature of sustainability". In general, all the interviewees believed that it has not been significantly paid attention in developing academic curricula. In this section, the important note emphasized by some experts is that the establishment of interdisciplinary courses is one of the requirements of sustainability in the form of academic efforts. In this regard, it should be said that adjacent disciplines have the greatest impacts on each other and any innovation is firstly spread to neighboring disciplines (Barzegar, 2008). Since solving problems ahead requires data and information from different fields of science, different disciplines shouldn't address this issue separately. One of the professors highly acclaimed the establishment of Future Studies discipline in some universities such as Tehran University; because such disciplines increase the ability to solve problem and manage in addition to fostering forward-looking perspective in people. Another important point raised by some interviewees in teaching sustainability, providing the possibility of a dialogue between students of different disciplines, universities and even other countries in the form of joint courses and programs, at least virtually. One of the interviewees said: "it is impossible to discuss about sustainability just in the class, if we don't learn how to talk with each other, if we don't know the global concerns, if we don't know how to interact and tolerate, not only no step will be taken to promote the values of sustainability, but this important issue, like other issues, will remain in theoretical form...". Another professor, who is one of the senior professors in political science, in this regard, said: "Unfortunately, universities have no special program for this interaction, even exchange of professors and students in Iran is not targeted. Personally, I'm trying to persuade the students to talk and discuss in my classroom and at least, in a class managed by myself, I do my duty, because I believe that, when the class becomes out of the monologue and not only professor plays a role in learning, the students will be motivated and certainly, in this friendly atmosphere, more possibilities arise to transfer values and objectives". Accordingly, today, beyond traditional methods, new teaching methods, including teaching with students' participation or teaching in the form of problem-solving are emphasized. In this form of teaching, everyday issues or concerns are expressed and students are asked to find the ways to fix them.

The role of professor in classroom was emphasized by some interviewees. If professor institutionalizes the values of sustainability in him/herself and provides the opportunity to discuss and critique in the classroom and trains critic, creative and thinker students with his/her behavior, he/she will take the most important step in 
promoting sustainability. These are expressed by a professor in political science who educated and taught in European universities. In this regard, he said: "Unfortunately, a view from the top to students is dominated by professors and this promotes some negative values, in European universities where I experience, the professors teach students some behaviors such as discipline, responsibility and respect in the unwanted form with their behaviors, manners, the way of speaking, classroom management and providing various and voluntary programs; there is no such spirit in classes and academic environment in Iran".

\section{Academic Research and Sustainability}

One of the professors in political science, who is one of activists in the field of peace, has emphasized on the role of academic research and referred to the triangle with the vertices of attitudes, behavior and knowledge and known the change in people's mentality as the most important step in promoting sustainability. According to him, the most important effectiveness of university is to produce required knowledge that according to it, knowledge and its transfer change the mentality of society through education and leads to the formation of behavioral patterns. In general, this point was stressed in interviews that the first step to develop and promote sustainability is to produce the appropriate literature. One of the professors and researchers in the field of higher education, believed that if only university is the institutions of knowledge production, it can has emancipatory function; it means university can be a ground of promotion of values related to sustainability if it produces the knowledge needed for this. In fact, the needed knowledge on what sustainability is, how it is developed, how it should be institutionalized in people's everyday lives and even the strategies to promote it, must be produced and then, its importance, quality and quantity must be determined for individuals, policy-makers and authorities through education. About the research, it was emphasized to conduct interdisciplinary research.

Another professor in political science and international relations emphasized on the paradigm shift in international circles, moving from hard power to soft power and the importance of margins and knew paradigm shift and providing a new paradigm as a fundamental step in realization of sustainability. According to him, defining and developing a new paradigm based on current conditions is the task of research institutions, especially academic research and also he said: "we talk about the need for a new paradigm in solving global issues. Production and promotion of this paradigm is not the duty of authorities; it is the duty of universities to investigate the issues and to try to develop a new paradigm to solve and manage current problems and this requires the collaboration of scholars and researchers in all the disciplines and fields of studies". In fact, it is important that the in studies on this field, the concepts, methods and information of different academic disciplines and sciences are considered to develop a model of sustainability. According to many scholars, such as Cortes, the duty of universities is beyond the mere training of sustainability and its dimensions and they know modeling sustainability as the higher task of higher education institution. Thinking about sustainability simultaneously requires systematic solutions to create thriving, strong and healthy communities economically, although the tendency is that all aspects of sustainability, including health, economic, political, security, environmental, and ... aspects, are considered separately. Accordingly, higher education has followed the development of sciences and specialized disciplines and individual learnings in this field (Hignite, 2006). At the present time, it is believed that universities and other higher education institutions should shape and promote the knowledge that helps to social development as well as economic development. In this regard, universities and higher education institutions play a crucial role in developing knowledge-based societies and knowledge-based economy (Carayannis \& Campbell, 2012). These institutions produce new knowledge through research and support governments and businesses by providing advice and strategies. In many countries, higher education institutions also play an influential role in determining social identity, pluralism and democracy (world bank, 1994). Given the importance of the issue, today, some universities have focused their efforts more on research than education.

\section{Social Responsibility of Universities and Sustainability}

Almost all of the interviewees believed that developing and promoting sustainability are not limited only to academics and elite and only when the principles and values of sustainability are institutionalized in all individuals, the sustainability can be discussed. So, it is worthy that universities follow a program to promote sustainability among the public. This must appear both in education and research. Implementing programs and holding workshops to promote the principles of sustainability was one of the issues mentioned. But what further emphasized was the role of research related to sustainability. One of the former official of the Ministry of Science believe that "all the research efforts and articles written by professors and students are published in research-scientific journals and other sources that elites read them and the ordinary people don't usually read them. If the literature on about good citizenship, respect for themselves, others and nature, tolerance and the role of dialogue in solving problems instead of conflict and tension, altruism, respect for justice and denouncement of 
inequality and discrimination are continuously generated and promoted in the form of sources such as newspapers that the public have access to them, good results will be certainly obtained in the long run". In this regard, one of the professors believed that given the important role of scientific-research and ISI journals in the promotion of professors or their role in students' thesis defense meeting, if the literature on sustainability is actually generated, it is exclusive to the elites and society do not benefit from it. So, some Measures should be taken so that this literature will be entered into people's lives. Another professors in the field of higher education emphasized on students' role towards the society. He said that we should teach students in a way that not only he/she accept the desired values in the best way by him/herself, but also, after finishing education and leaving university, he/she transfers the values to another people, from family to friend and the society and the society gradually accept that it should be learning constantly. In fact, the learning community is one of the prerequisites for sustainability.

On how to organize these activities, one of the things that attracted the attention of some interviewees, was that the university can have a defined program and action plan, if it is autonomous. University must provide plan and program away from the government and bureaucracy. Some interviewees, with skepticism about the administration system, believed that if we want to get the verification of each plan, even if it is small, the plan won't be finally acted. Independence is one of the most important features that can lead to sustainable education. The independence greatly reduces the vulnerability of university so that it is not impaired by changing a person. The government can also provide the grounds of optimal production of knowledge in addition to support and monitoring. Only with independence, autonomy and academic freedom and professional independent management and through international free cooperation, can take this mission can and be responsive to community and seriously participate and play an effective role in the eradication of poverty, illiteracy, hunger, social pathologies, anomie, alienation, fear and anxiety, illness and in the enlightenment about the harmful effects of intolerance, violence and the deterioration of the environment and so on (Ferasatkhah, 2010). The point also mentioned in some interviews was further collaboration between decision making system and academic system and use of academic potential in solving the current problems. Some professors argued that many research projects, articles and dissertations have been not used. One of professors said: "academics and executives are similar to two separate islands. This makes academic researchers impassion, personally, I sometimes feel that my efforts and research are useless; because ultimately it is used only for promotion". Strong and efficient management with creative attitude to development, a detailed program which is constantly revised in accordance with the terms and strong oversight groups that can raise accountability, are other cases were paid attention. In general, the interviewees' comments can be concluded as Figure 3: 


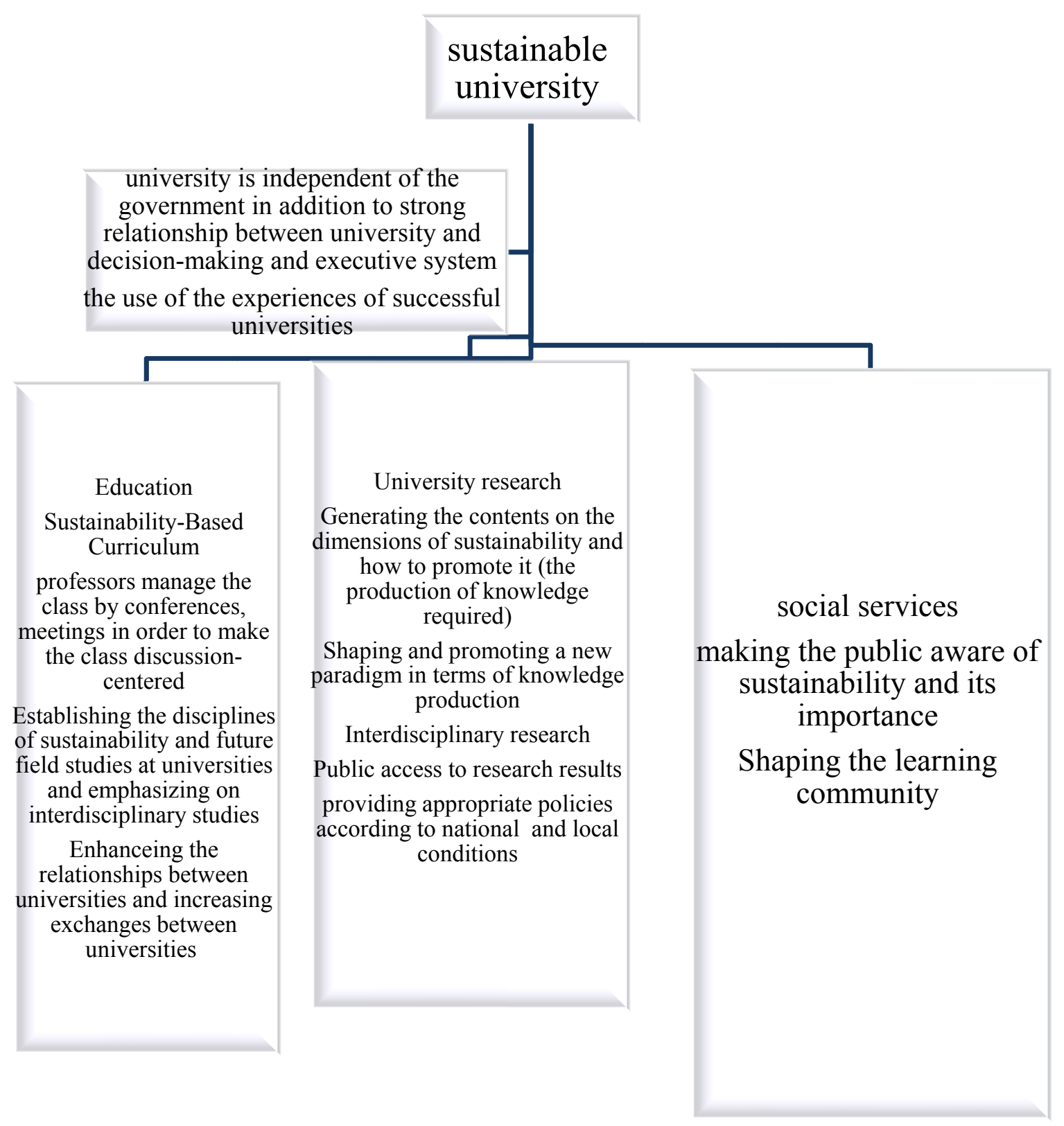

Figure3. The interviewees' comments about the role of university in promoting sustainability

\section{Suggestions}

If we know individuals' knowledge as the first step towards sustainable development and the university as an institution to promote knowledge, this institution cannot follow innovative programs in this regard without detailed planning. The role of university, type of programs and how to organize the measures were investigated and analyzed by in-depth interview with experts and professors who have experienced in this regard and accordingly, some suggestions are provided as follows:

- It is necessary that the Ministry of Science, Research and Technology and

- Ministry of Health pay more attention to the importance of this issue and put it on the agenda for appropriate policy-makings and further cooperation with universities

- $\quad$ The establishment of discipline with the title of sustainability and peace studies (interdisciplinary) 
- The development of some disciplines such as future studies

- Providing general curses on sustainability and peace as a two-unit course

- Training professors about how to behave in classroom and new teaching methods

- Choosing forward-looking and creative heads

- Making some activities such as exchange of students and professors, targeted in a way that they can provide some teachings to others after returning

- Making academic research targeted and institutionalizing the goal that the mission of universities is to produce knowledge and to change the current views and to support research

- The establishment of research universities and the need to pay attention to them

- Changing the promotion system of professors and considering privileges for the contents which are published out of research-scientific journals so that ordinary people benefits from them.

- Paying attention and investigating international experiences and the experiences of other leading universities, so that their experiences are applied according to local conditions

- Recognizing the independence of universities by the relevant ministries. Universities should be free in developing and implementing the programs of sustainability and administrative procedures would not prevent them.

According to what mentioned, it can be concluded that higher education system is dynamic system and it should be susceptible to environmental conditions and global requirements and demands. In order to play an effective role in this regard, university needs to revise the structure, content and academic missions. Therefore, an important principle of academic freedom should be recognized by the government; this means that the government should recognize the independent decision-making right of university in addition to financial support. Such university needs a very strong and efficient management to make innovative and creative decisions in addition to having independence so that university would be more effective in movement towards sustainability. In general, using the capacity of universities in the realization of sustainable development needs comprehensive and macro view of policy-makers, executives and academics so that they can consult and cooperate with each other to fulfill this goal.

\section{References}

Afgan, N. H., \& Carvalho, M. G. (2010). The Knowledge Society: A Sustainability Paradigm. Cadmus, I(1).

Akhundi, M., Pourshafeii, H., \& Rashedi, F. (2013). the Role of Human Resources in Sustainable Development with Higher Education Approach, Tehran, Proceedings of the International Conference on Higher Education and Sustainable Development, Institute for Research and Planning in Higher Education.

Barzegar, I. (2008). Nature History and philosophy of the creation of interdisciplinary sciences. Journal of Interdisciplinary studies in the humanities, (2).

Brubacher, J. S. (1977). On the Philosophy of Higher Education. Jossey -Bass, San Francisco.

Calder, W., \& Dautremont - Smith, J. (2009). Higher Education: More and More Laboratories for Inventing a Sustainable Future. Retrieved from www.uslf.org/pdf/ESDHigherEdamericaCalder2009.pdf

Carayannis Elias, G., \& Campbell David, F. J. (2012). Epistemic Governance in Higher Education. Springer, New York.

Cortes, A. D. (2003). The Critical Role of Higher Education on Creating a Sustainable Future, Planning for Higher Education, March-May. Retrieved from http://www.aashe.org/resources/pdf/Cortese_PHE.pdf

Delanti, G. (2007). The challenge of knowledge, universities in knowledge society, translated by Bakhtiarizadeh, A, Tehran, Institute of Social and Cultural Studies.

Doane, D., \& Gillivray, A. M. (2001). Economic Sustainability The business of staying in business New Economics Foundation, The SIGMA project in Harvard University. Retrieved from http://isites.harvard.edu/fs/docs/icb.topic140232.files/RD_economic_sustain.pdf

Ferasatkhah, M. (2010). How can we have high quality universities? Journal of Education Message, (8).

Ferrer - Balas, D., \& Muler, K. (2005). Enginering Education in Sustainable Development. International Journal of Sustainability in Higher Education, 6(3).

Grober, U. (2007). A conceptual history of sustainable development. Retrieved from 
https://www.wzb.eu/www2000/alt/uta/pdf/P\%202007-002\%20final.pdf

Hignite, K. (2006). Will Sustainability Take Root? National Association of College and University Business $\begin{array}{llll}\text { Officers } & \text { (NACUBO). Retrieved }\end{array}$ http://www.nacubo.org/Business_Officer_Magazine/Magazine_Archives/April_2006/Will_Sustainability_T ake_Root.html

Javdani, H., \& Nili monfared, J. (2013). Sustainable university: A pathway for highway survival, Proceedings of the Second International Conference on Higher Education and Sustainable Development, Institute for Research and Planning in Higher Education.

Kates, R. W., Parris, T. M., \& Leiserowitz, A. A. (2005). What is Sustainable Development? Goals, Indicators, Values, and Practices. Environment: Science and Policy for Sustainable Development, 47(3).

Kildahl, A. (2009). Advancing higher education for sustainability in Asia in a period of rapid growth challenges and opportunities. Symposium Paper. Retrieved from www.hku.hk

Malekinia, A. et al. (2014). Identification and prioritization of components of sustainable University. Journal of Research and Planning in Higher Education, 20(3).

McKenzie, S. (2004). Social Sustainability: Towards Some Definitions, Hawke Research Institute Working Paper Series, No 27.

Molaee, J. (2007). The third generation of human rights and the right to a healthy environment, Quarterly of law, Faculty of Law and Political Sciences, Tehran University, Volume 37, Issue 4.

Moren, E. (2005). Globalization and Education, seven knowledge necessary to educate the future, translated by Javdani, H., Tehran, Institute of Management and Planning Education and Research.

Mosaei, A., \& Ahmad Zadeh, M. (2009). Development education and sustainable development. Journal of strategy, (18).

Partidario, M. R., Vicente, G., \& Belchior, C. (2010). Can New Perspectives on Sustainability Drive Lifestyles? Retrieved from http://www.mdpi.com/2071-1050/2/9/2849/pdf

Smarandache, F., \& Vlăduţescu, Ş. (2012). The Fifth Function of University: Neutrosophic E-function" of Communication-Collaboration-Integration of University in the Information Age. Retrieved from http://www.gallup.unm.edu/ smarandache/Neutrosophic-e-Function.pdf

Steiner, G., \& Posch, A. (2006). Higher education for sustainability by means of transdisciplinary case studies: an innovative approach for solving complex, real-world problems. Journal of Cleaner Production, 14(9-11). https://doi.org/10.1016/j.jclepro.2005.11.054

Toh, S., \& Floresca- Cowagas, F. (1989). Peace Education: a Framework for the Philippines. Quezon City: Phoenix Publishing House.

UN. (1997). Agenda for Development. Retrieved from http://www.un.org/documents/ga/res/51/ares51-240.htm

UNESCO. (2004). Education for Sustainable Development Information Brief. UNESCO, Paris.

Weenen, H. V. (2000). Towards a vision of a Sustainable University. International Journal of Sustainability in Higher Education, (1). https://doi.org/10.1108/1467 630010307075

Winston, M. (2011). Sustainability and Social Justice. International Journal of Business and Social Science, 2(16).

Zaker Salehi, Gh. (2013). Higher education in transition from sustainable development to post-sustainability, Proceedings of the Second International Conference on Higher Education and Sustainable Development, Institute for Research and Planning in Higher Education.

\section{Copyrights}

Copyright for this article is retained by the author(s), with first publication rights granted to the journal.

This is an open-access article distributed under the terms and conditions of the Creative Commons Attribution license (http://creativecommons.org/licenses/by/4.0/). 